\title{
A Prospective Bicenter Study Investigating the Diagnostic Value of Procalcitonin in Patients with Acute Appendicitis
}

\author{
M. Sand ${ }^{a}$ X.V. Trullen ${ }^{c}$ F.G. Bechara ${ }^{b}$ X.F. Palac ${ }^{c}$ D. Sand ${ }^{d}$ G. Landgrafe ${ }^{a}$ \\ B. Mann ${ }^{a}$ \\ aDepartment of General and Visceral Surgery, Augusta Krankenanstalt, Academic Teaching Hospital, and \\ ${ }^{b}$ Department of Dermatology and Allergy, University of Bochum, Bochum, Germany; ${ }^{\mathrm{C} D e p a r t m e n t}$ of General and \\ Visceral Surgery, Hospital de Igualada, Consorci Sanitari de I'Anoia, Igualada, Spain; ${ }^{\mathrm{d}}$ Department of \\ Physiological Science, University of California Los Angeles (UCLA), Los Angeles, Calif., USA
}

\section{Key Words}

Procalcitonin · Appendicitis · Diagnostic

\begin{abstract}
Background: Procalcitonin (PCT) is an established laboratory marker for disease severity in patients with infection and sepsis. In addition, PCT has been shown to be an effective marker for a limited number of localized infections. However, whether or not PCT has any diagnostic value for acute appendicitis, still remains unclear. The purpose of this prospective bicenter study was, therefore, to determine whether or not the PCT levels in the serum of patients with acute appendicitis have any diagnostic value. Methods: This prospective study included 103 patients who received an appendectomy, based on the clinical diagnosis of acute appendicitis, in a surgical department of an academic teaching hospital in Germany or in a county hospital in Spain. White blood cell count (WBC), C-reactive protein (CRP) and procalcitonin (PCT) values were determined preoperatively. All appendectomy specimens were sent for routine histopathological evaluation. Based on this information, the patients were assigned to 1 of 5 groups that reflected the severity of the appendicitis. Results: Of the 103 patients who were included in the study, 98 had appendicitis. Fourteen (14.3\%)
\end{abstract}

showed an increase in PCT values. Of those 14,4 had a serum $\mathrm{PCT}>0.5 \mathrm{ng} / \mathrm{ml}, 9 \mathrm{had}$ a PCT value $>2-10 \mathrm{ng} / \mathrm{ml}$ and $1 \mathrm{had} \mathrm{a}$ PCT value $>10 \mathrm{ng} / \mathrm{ml}$. The sensitivity of PCT was calculated to be 0.14 . The mean $\mathrm{WBC}$ value was $13.0 / \mathrm{nl}( \pm 5.2,3.4-31$ ), and for CRP it was $8.8 \mathrm{mg} / \mathrm{dl}$ ( $\pm 13,0-60.2$ ). The values of CRP, WBC and PCT increased with the severity of the appendicitis. Conclusions: PCT is potentially increased in rare cases of severe inflammation and, in particular, after appendiceal perforation or gangrenous appendicitis. However, its remarkably low sensitivity prohibits its routine use for the diagnosis of appendicitis.

Copyright $\odot 2009$ S. Karger AG, Basel

\section{Background}

Acute appendicitis is still the most frequent cause of right lower quadrant pain and the most common acute surgical condition of the abdomen. Acute appendicitis remains one of the most serious abdominal illnesses. It is a pathological condition that requires immediate surgical treatment. Its reported overall mortality rate is $0.3 \%$, which rises considerably in cases of perforation (6.5\%), older patients $(5.5 \%)$ or neonates $(80 \%)$ [1]. Ultimately, advanced bacterial peritonitis following perforation of

\section{KARGER}

Fax +41613061234 E-Mail karger@karger.ch www.karger.com
(C) 2009 S. Karger AG, Basel

0014-312X/09/0433-0291\$26.00/0

Accessible online at:

www.karger.com/esr
Michael Sand, MD

Department of General and Visceral Surgery

Augusta Krankenanstalt - Academic Teaching Hospital, Ruhr University Bochum Bergstr. 26, DE-44791 Bochum (Germany)

Tel. +49 234 5170, Fax +49 234517 2503, E-Mail michael.sand@ruhr-uni-bochum.de 
the inflamed appendix can reach a natural mortality rate as high as $80-100 \%$, which underlines the potential lifethreatening danger that is still caused by this common disease.

The frequency of appendicitis and the high rates of negative appendectomies, reported to be between 9 and $44 \%$, have led to continuing efforts to develop new diagnostic methods that have the highest possible sensitivity and specificity in order to reduce the rate of negative appendectomies [2].

Despite the multiple modern diagnostic tools that are available, diagnosis of acute appendicitis is still primarily done by history and physical examination. Additional diagnostic measures like temperature measurement, urinalysis and laboratory tests are routinely performed.

The clinical diagnosis of appendicitis remains a challenge as a variety of differential diagnoses have to be considered as causative for right lower quadrant pain. The laboratory tests that are useful for the diagnosis of acute appendicitis are white blood cell count (WBC), C-reactive protein (CRP) and erythrocyte sedimentation rate. Another laboratory value that has recently received considerable attention for the early diagnosis of bacterial infection and sepsis is procalcitonin (PCT). In recent studies, PCT has clearly been shown to be one of the most important biochemical indicators that closely correlate with the severity of the inflammatory host response to microbial infections [3]. The aim of this open, prospective bicenter study is, therefore, to investigate whether or not PCT offers an accurate diagnostic tool for acute appendicitis.

\section{Methods}

This study originates from a surgical department of an academic teaching hospital (Augusta Krankenanstalt, Ruhr University Bochum, Germany) and the surgical department of a county general hospital (Hospital de Igualada, Consorci Sanitari de l'Anoia, Igualada, Spain). It was conducted within the framework of the declaration of Helsinki and approved by the Ethics Review Board of the Ruhr-University Bochum, Germany (registration No.: 3133-08, ClinicalTrials.gov identifier: NCT00630071). Informed consent was obtained from the study subjects.

\section{Patients}

All patients who were clinically diagnosed as having acute appendicitis between June 2007 and June 2008 were included in the study.

The exclusion criteria were prior antibiotic therapy, an age $<10$ years, pregnancy and other known inflammatory conditions or infections.

The diagnosis was made by the attending surgeon, based upon the patient's history and clinical examination. When possible,
Table 1. Description of the 5 groups to which patients were assigned based on severity of inflammation

\begin{tabular}{ll}
\hline Group & Description \\
\hline 1 & no pathological findings \\
\hline 3 & reactive follicular hyperplasia or chronic appendicitis \\
\hline 4 & $\begin{array}{l}\text { acute appendicitis, intact appendiceal mucosa and a } \\
\text { mild to moderate infiltration of the inflammatory cells }\end{array}$ \\
$\begin{array}{l}\text { macroscopically or histologically perforated acute ap- } \\
\text { nied by a strong panmural infiltrate of the inflamma- } \\
\text { tory cells }\end{array}$ \\
\hline 5 & acute necrotizing appendicitis \\
\hline
\end{tabular}

laparoscopic appendectomy was favored. In some rare cases, when the laparoscopic approach was not possible, the appendectomy was performed conventionally. All appendectomy specimens were sent for routine histopathological evaluation.

Following the study by Kafetzis et al. [4], who investigated PCT as a predictor of severe appendicitis in children, we divided our patients into 5 groups depending on the pathological findings (table 1). Group 1 consisted of patients who had no pathological findings. Group 2 included patients who had reactive follicular hyperplasia or chronic appendicitis. Group 3 comprised patients who had acute appendicitis, intact appendiceal mucosa and a mild to moderate infiltrate of inflammatory cells. Group 4 consisted of patients who had macroscopically or histologically perforated acute appendicitis or perforated appendiceal mucosa that was accompanied by a strong panmural infiltrate of inflammatory cells. Group 5 consisted of patients who had acute necrotizing appendicitis. Histology at each study site was performed by a single pathologist in order to minimize intraobserver variation.

\section{Laboratory Parameters}

The concentration of PCT from the German patients was determined using an enzyme-linked fluorescent assay VIDAS $^{\circledR}$ PCT; B.R.A.H.M.S. AG, Henningsdorf, Germany). The assay principle combined a 1-step immunoassay sandwich method with a final fluorescent detection performed in an automated VIDAS ${ }^{\circledR}$ instrument (bioMérieux SA, Marcy l'Etoile, France). The concentrations of PCT from the Spanish patients were determined using PCT-Q (B.R.A.H.M.S. AG), a self-developing, solid-phase immunoassay, according to the manufacturer's protocol. The leukocyte count of each patient was determined with an electronic cell counter (Sysmex XE-2100; Sysmex Digitana AG, Horgen, Switzerland). The serum CRP measurement combined an in vitro particle-enhanced immunoturbidimetric assay with a quantitative determination of CRP in human serum using an automated clinical chemistry analyzer (Roche ${ }^{\circledR}$ Modular Analytics P 800, Roche, Mannheim, Germany) in combination with a commercially available standardized test kit (Tina-quant CRP Latex; Roche Diagnostics $\mathrm{GmbH}$, Mannheim, Germany). Normal values were defined as $4.4-11.3 / \mathrm{nl}$ for WBC, $<0.5 \mathrm{mg} / \mathrm{dl}$ for CRP and $<0.5 \mu \mathrm{g} / \mathrm{ml}$ for PCT. 
Statistics

Statistical analysis was performed using SPSS 11.0 for Windows. Analysis of the data distribution was assessed by the Kolmogorov-Smirnov test. For normally distributed data (WBC), the null hypothesis was based on the assumption that no difference in values existed between the 5 groups that were studied in the present trial. One-way ANOVA for 5 independent samples was used for interarm comparisons. The Scheffe procedure for pairwise comparisons was subsequently used to determine which group was significantly different from any other in terms of WBC value.

In the case of unequal data distribution (CRP), the KruskalWallis test (nonparametric independent-group comparison) was used to compare groups. The Mann-Whitney U Test was applied to compare different groups among themselves. The PCT values were analyzed by means of $\chi^{2}$ analysis. Mean values and standard deviations (SD) were calculated for WBC and CRP. Additional calculations of sensitivity, specificity, negative predictive value (NPV) and positive predictive value (PPV) of PCT, WBC and CRP for the diagnosis of appendicitis were included in the data analysis. Statistical significance was set at the $5 \%$ level (2-sided).

\section{Results}

A total of 103 patients (46 female, 57 male, median age \pm SD: $33 \pm 18.5$ years, range: $10-86)$ with clinical signs of acute appendicitis who received an appendectomy were enrolled in the study. After a review of the operation and the pathology record, the patients were classified into 1 of 5 groups (table 1). Group 1 included a total of 5 patients (4.8\%), group 2 comprised 14 patients (13.6\%), group 3 consisted of 60 patients (58.3\%), group 4 included 20 patients (19.4\%) and group 5 comprised 4 patients (3.9\%; fig. 1).

\section{Demographics and Treatment}

Two patients from group 1 (40\%), 5 patients from group 2 (36\%), 17 patients from group 3 (28\%) and 1 patient from group 4 (2\%) were 18 years of age or younger. The prevalence of women was noticeably higher in group $2(71 \%)$, whereas men were more often affected in group 4 (60\%). In groups 1 and 5, the ratio of men to women was almost equal (table 2). The surgical treatment was laparoscopic $(n=82)$, open $(n=16)$ or conversion appendectomy $(\mathrm{n}=5)$. The mean duration of the hospital stay was 4.7 days $(\mathrm{SD}=2.9$, range $=2-21)$. The details are compiled in table 2 .

\section{Laboratory Results}

The PCT values were elevated in 14 of the 98 patients (14.3\%) with some form of appendicitis. Of those 14 patients, none $(0 \%)$ were from group $1(n=5), 1(7 \%)$ was from group $2(\mathrm{n}=14), 4(7 \%)$ were from group $3(\mathrm{n}=60)$,

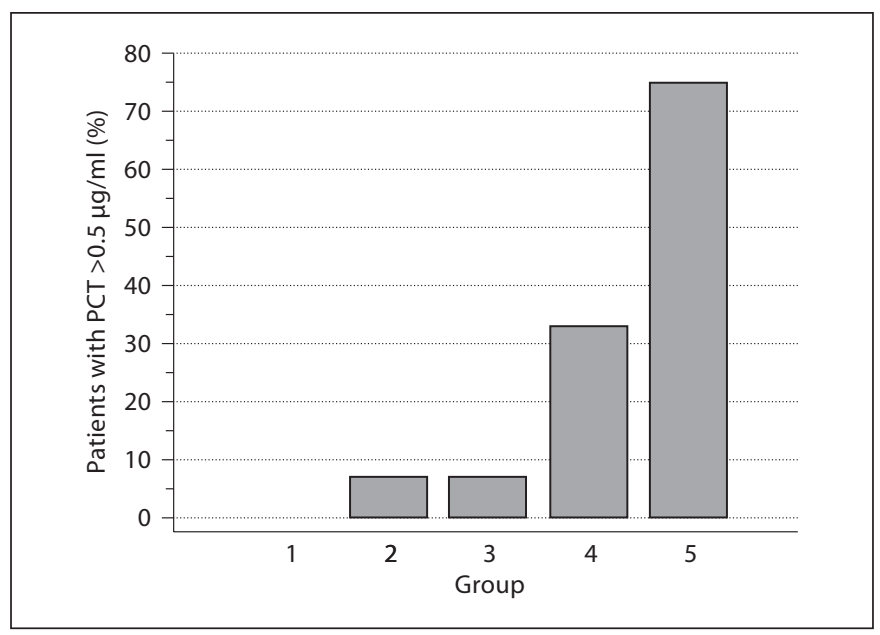

Fig. 1. Percentage of patients with elevated PCT levels $(>0.5 \mu \mathrm{g} /$ $\mathrm{ml})$ among groups $1-5$.

$6(33 \%)$ were from group $4(n=20)$ and $3(75 \%)$ were from group $5(\mathrm{n}=4)$ (fig. 1). Four patients had PCT values between 0.5 and $2 \mu \mathrm{g} / \mathrm{ml}$, none had PCT values of $2-10 \mu \mathrm{g} /$ $\mathrm{ml}$, and 1 had PCT values $>10 \mu \mathrm{g} / \mathrm{ml}$. The sensitivity of PCT for the diagnosis of acute appendicitis was 0.14 , with a specificity of 1 . The PPV of PCT $(>0.5 \mu \mathrm{g} / \mathrm{ml})$ for appendicitis was 1 in contrast to 0.76 for CRP $(>0.5 \mathrm{mg} / \mathrm{dl})$ and to 1 for WBC. The NPV for appendicitis were 0.06 for PCT, 0.09 for WBC and 0.11 for CRP. Compared to group 1 (no appendicitis), the patients with appendicitis in the other groups (groups 2-5) had a significantly higher likelihood of having a PCT elevation $(\mathrm{p}<0.05)$. Details of the sensitivity, specificity and predictive values are compiled in table 3.

The mean values for $\mathrm{WBC}$ were $13 / \mathrm{nl}(\mathrm{SD}=5.2$, range $=$ 3.4-31). Statistical analysis showed that there was a significant difference in the WBC values between groups 1 and 5 as well as between groups 2 and 5, whereas group 5 showed significantly higher values overall $(\mathrm{p}<0.05)$. All other differences were not significant ( $p>0.05)$ (fig. 2).

The mean CRP value was $8.8 \mathrm{mg} / \mathrm{dl}(\mathrm{SD}=13$, range $=$ $0-60.2)$. Comparison among the groups showed significantly higher values in groups 4 and 5 compared to groups $1-3$ ( $\mathrm{p}<0.05$ ). Group 3 also showed significantly higher CRP values compared to group $2(\mathrm{p}<0.05)$. All other differences among the groups were not significant $(\mathrm{p}>0.05$; fig. 3).

Overall, with regard to WBC, CRP and PCT values, there was an increase in the mean values from group 2 to group 5, which reflected the severity of the appendicitis. The laboratory findings are compiled in table 2 . 
Table 2. Details of laboratory values, epidemiology and treatment of the 5 groups in the present study

\begin{tabular}{|c|c|c|c|c|c|c|c|c|}
\hline Group & $n$ & Age, years & Sex & $\begin{array}{l}\text { WBC } \\
{[4.4-11.3 / \mathrm{nl}]}\end{array}$ & $\begin{array}{l}\text { CRP } \\
{[<0.5 \mathrm{mg} / \mathrm{dl}]}\end{array}$ & PCT & Therapy & $\begin{array}{l}\text { Duration of } \\
\text { hospital stay } \\
\text { days }\end{array}$ \\
\hline 1 & 5 & $\begin{array}{l}22.8 \\
( \pm 18.5,16-31)\end{array}$ & $\begin{array}{l}3 \mathrm{f} \\
2 \mathrm{~m}\end{array}$ & $\begin{array}{l}8.3 \\
( \pm 2,6.2-11)\end{array}$ & $\begin{array}{l}1.5 \\
( \pm 2.2,0.2-5.3)\end{array}$ & $0[>0.5 \mathrm{ng} / \mathrm{ml}],(0 \%)$ & $\begin{array}{l}4(\mathrm{~L}) \\
1(\mathrm{CA})\end{array}$ & $\begin{array}{l}3.2 \\
( \pm 1.1,2-4)\end{array}$ \\
\hline 2 & 14 & $\begin{array}{l}25.7 \\
( \pm 13.6,14-69)\end{array}$ & $\begin{array}{l}10 \mathrm{f} \\
4 \mathrm{~m}\end{array}$ & $\begin{array}{l}9.4 \\
( \pm 2.9,5.7-14.6)\end{array}$ & $\begin{array}{l}3.7 \\
( \pm 8,0-28.5)\end{array}$ & $1[>10 \mathrm{ng} / \mathrm{ml}],(7 \%)$ & $\begin{array}{r}3(\mathrm{O}) \\
11(\mathrm{~L})\end{array}$ & $\begin{array}{l}5.6 \\
( \pm 3.4,2-15)\end{array}$ \\
\hline 3 & 60 & $\begin{array}{l}17.4 \\
( \pm 13.6,10-77)\end{array}$ & $\begin{array}{l}24 \mathrm{f} \\
36 \mathrm{~m}\end{array}$ & $\begin{array}{l}13.2 \\
( \pm 4.7,3.4-28)\end{array}$ & $\begin{array}{l}6.0 \\
( \pm 6.8,0.1-28.2)\end{array}$ & $\begin{array}{l}3[>0.5 \mathrm{ng} / \mathrm{ml}],(5 \%) \\
1[>2-10 \mathrm{ng} / \mathrm{ml}],(1.7 \%)\end{array}$ & $\begin{aligned} & 7(\mathrm{O}) \\
52 & (\mathrm{~L}) \\
1 & (\mathrm{CA})\end{aligned}$ & $\begin{array}{l}3.9 \\
( \pm 2.7,2-21)\end{array}$ \\
\hline 4 & 20 & $\begin{array}{l}39.7 \\
( \pm 21.1,14-86)\end{array}$ & $\begin{array}{c}7 \mathrm{f} \\
13 \mathrm{~m}\end{array}$ & $\begin{array}{l}14.7 \\
( \pm 5.8,5-31)\end{array}$ & $\begin{array}{l}17.4 \\
( \pm 17.3,0.1-51.8)\end{array}$ & $\begin{array}{l}1[>0.5 \mathrm{ng} / \mathrm{ml}],(5 \%) \\
5[>2-10 \mathrm{ng} / \mathrm{ml}],(25 \%)\end{array}$ & $\begin{aligned} & 4(\mathrm{O}) \\
14 & (\mathrm{~L}) \\
& 2(\mathrm{CA})\end{aligned}$ & $\begin{array}{l}5.9 \\
( \pm 1.3,3-9)\end{array}$ \\
\hline 5 & 4 & $\begin{array}{l}56.3 \\
( \pm 22.1,29-81)\end{array}$ & $\begin{array}{l}2 \mathrm{f} \\
2 \mathrm{~m}\end{array}$ & $\begin{array}{l}18.6 \\
( \pm 7.8,9-28)\end{array}$ & $\begin{array}{l}35.1 \\
( \pm 29.7,1.9-60.2)\end{array}$ & $3[>2-10 \mathrm{ng} / \mathrm{ml}],(75 \%)$ & $\begin{array}{l}2(\mathrm{O}) \\
1(\mathrm{~L}) \\
1(\mathrm{CA})\end{array}$ & $\begin{array}{l}10 \\
( \pm 3.2,6-13)\end{array}$ \\
\hline Total & 103 & $\begin{array}{l}33 \\
( \pm 18.5,10-86)\end{array}$ & $\begin{array}{l}46 \mathrm{f} \\
57 \mathrm{~m}\end{array}$ & $\begin{array}{l}13.0 \\
( \pm 5.2,3.4-31)\end{array}$ & $\begin{array}{l}8.8 \\
( \pm 13,0-60.2)\end{array}$ & $\begin{array}{l}4[>0.5 \mathrm{ng} / \mathrm{ml}],(4.1 \%) \\
9[>2-10 \mathrm{ng} / \mathrm{ml}],(9.2 \%) \\
1[>10 \mathrm{ng} / \mathrm{ml}],(1 \%)\end{array}$ & $\begin{array}{l}16(\mathrm{O}) \\
82(\mathrm{~L}) \\
5(\mathrm{CA})\end{array}$ & $\begin{array}{l}4.7 \\
( \pm 2.9,2-21)\end{array}$ \\
\hline
\end{tabular}

Figures in parentheses represent SD and ranges, and normal values are given in square brackets. PCT: numbers and percentages of patients. $\mathrm{f}=$ Female $\mathrm{m}=$ male $\mathrm{O}=$ open appendectomy; $\mathrm{L}=$ laparoscopic appendectomy; $\mathrm{CA}=$ conversion to open appendectomy.

Table 3. Sensitivity, specificity, PPV and NPV for appendicitis calculated for PCT, WBC and CRP

\begin{tabular}{lllll}
\hline Laboratory results & Sensitivity & Specificity & PPV & NPV \\
\hline PCT $(>0.5 \mu \mathrm{g} / \mathrm{ml})$ & 0.14 & 1 & 1 & 0.06 \\
WBC $(>12.1 / \mathrm{nl})$ & 0.47 & 1 & 1 & 0.09 \\
CRP $(>0.5 \mathrm{mg} / \mathrm{dl})$ & 0.72 & 0.6 & 0.76 & 0.11 \\
\hline
\end{tabular}

\section{Discussion}

PCT is a calcitonin precursor and has emerged as one of the most important early laboratory signs for systemic bacterial and fungal infection. The group of calcitonin precursors, including PCT, are encoded by the calcitonin I gene (CALC-I) on chromosome 11 [5]. In the absence of inflammatory stimuli, the transcription of the CALC-I gene is suppressed, except in neuroendocrine cells that are mainly found in the thyroid or lung. In healthy individuals, the normal plasma PCT levels are $<0.5 \mathrm{ng} / \mathrm{ml}$. In cases of microbial infection, severe systemic inflammation or sepsis, an increase in CALC-I gene expression occurs, with a concomitant rise in PCT levels in all tissues and cell types of the human body [6].
The circulating levels of the calcitonin precursors, including the prohormone PCT, have been shown to be increased up to several thousand-fold, reflecting the severity of the inflammation. Not only is PCT elevated in systemic infections, but it is also increased for somelocalized bacterial infections, such as in lower respiratory tract infections, meningitis, infectious endocarditis and pancreatitis, and its important diagnostic performance has been demonstrated for these localized infections [7-10].

In the early disease process, acute appendicitis is also regarded as a localized inflammatory process. However, the diagnostic potential of PCT has not been sufficiently investigated for this particular disease.

From a pathophysiological point of view, fecaliths, which naturally carry a high load of gram-negative bac- 


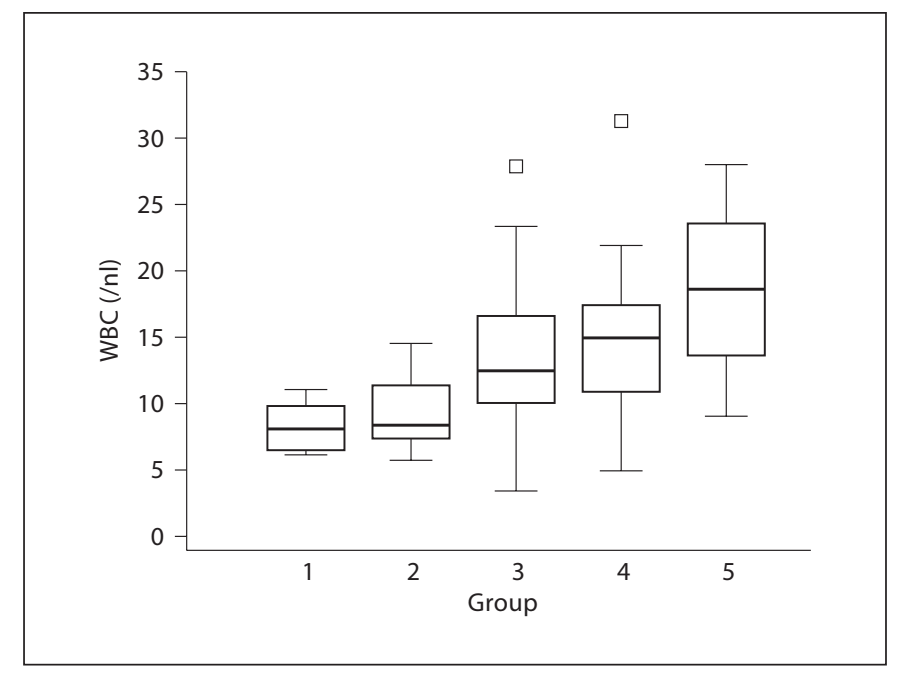

Fig. 2. WBC levels in groups $1-5$. The WBC levels showed significantly higher values in group 5 when compared to groups 1 and $2(\mathrm{p}<0.05)$.

teria, are thought to be the predominant factor for the obstruction of the appendiceal lumen in acute appendicitis. Over the course of the inflammatory process, mucosal secretion increases and the resident bacteria of the appendix start to multiply rapidly. The integrity of the appendix is compromised through an impaired blood supply, and the bacterial invasion begins to proceed with the release of bacterial endotoxins [11]. At the same time, it has been demonstrated that the injection of bacterial endotoxin into healthy subjects causes an increase in PCT by approximately $0.5 \mathrm{ng} / \mathrm{ml}$ per hour after a latency of about 2-3 h and reaching a plateau after 6-12 h [12]. Bacterial lipopolysaccharides are unique surface glycolipids and prototypical examples of bacterial endotoxins, which are found in the outer membrane of gram-negative bacteria. Bacterial lipopolysaccharides and the proinflammatory cytokines are the most potent inducers of PCT release. During a viral infection, the serum PCT concentrations were slightly elevated to $1.5 \mathrm{ng} / \mathrm{ml}$, whereas the levels during a bacterial infection reached up to $1,000 \mathrm{ng} / \mathrm{ml}$ [13]. Therefore, an increase in PCT in patients with acute appendicitis can be expected.

The available data evaluating the diagnostic value of PCT for patients with acute appendicitis are sparse and predominantly related to children. Acute appendicitis in adolescents or adults has rarely been subject of research regarding the diagnostic value of PCT. The only study available to date that investigated adult patients is by $\mathrm{Ki}$ -

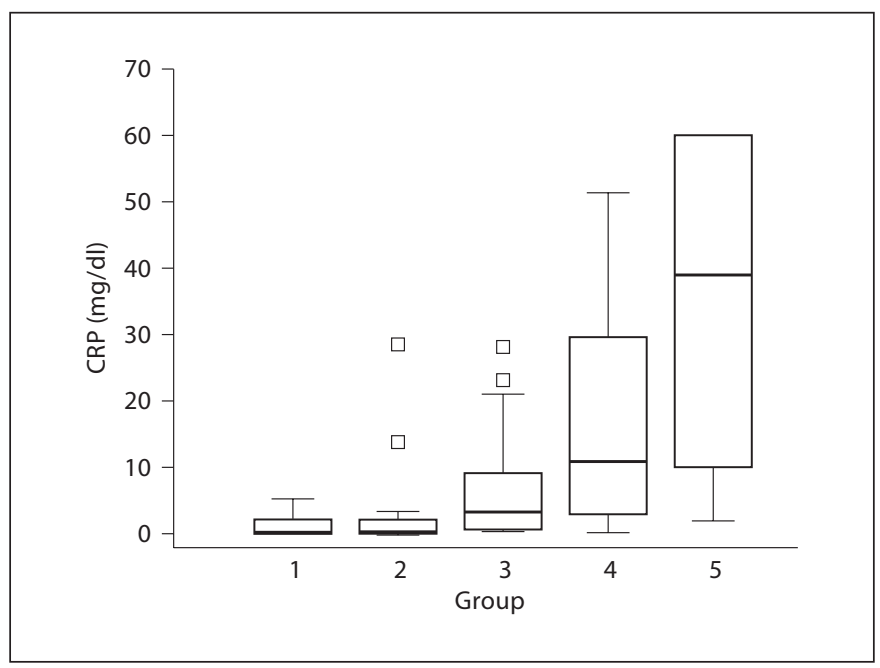

Fig. 3. CRP levels in groups 1-5. Notice the significantly higher CRP values in groups 4 and 5 as compared to group 1, 2 and 3 $(p<0.05)$. Group 3 showed significantly higher CRP values compared to group $2(\mathrm{p}<0.05)$.

sacik et al. [14], who studied 34 adult patients with acute appendicitis and 28 with familial Mediterranean fever attacks. They report PCT levels that are higher than 0.5 $\mathrm{ng} / \mathrm{ml}$ in $62 \%$ of their patients with acute appendicitis and in $11 \%$ of their patients with familial Mediterranean fever. When our data are compared with the latter findings, we see in their data a remarkably large fraction of patients with acute appendicitis who demonstrate a PCT increase, which is contradictory to our data. In our group of $98 \mathrm{pa}-$ tients with some form of appendicitis (severity 1-5), only $14(14.3 \%)$ had PCT levels $>0.5 \mathrm{ng} / \mathrm{ml}$. The sensitivity of PCT for the diagnosis of appendicitis was calculated to be 0.14 in our study, which is remarkably low and causes some doubt about the diagnostic potential of this laboratory marker. The other available data include children and adolescents, and these 4 studies show conflicting results $[4,15-17]$.

In contrast to the latter results, our patients showed that the likelihood of observing an elevation in PCT values increases with the severity of appendicitis. Groups 3, 4 and 5 showed a gradual increase in the proportion of patients with an elevation in the levels of PCT (7,33 and $75 \%)$.

In the present study, only 14 of 98 patients (14.3\%) with appendicitis showed an increase in PCT values, which leads us to conclude that PCT has no diagnostic value for acute appendicitis in adolescents or adults. This is also reflected by the poor sensitivity of 0.14 , which, from the 
authors' point of view, prohibits its usage as a potential diagnostic marker.

As our first results contradicted those reported by Kisacik et al. [14], very early on in our study, we began analyzing the method of determining the levels of PCT and specimen collection to rule out systematic errors that may have led to lower PCT concentrations than those reported by other authors. In addition, since the PCT controls, who were all septic patients from the surgical ICU of our respective departments, were positive and evaluated identically, we concluded that the measurement of PCT was without error.

In contrast, other inflammatory parameters, such as CRP and leukocytes, showed a correlation with the severity of appendiceal inflammation. This was expected, as had been shown before by other authors [18].

With regard to PCT, the question arises as to why acute appendicitis seems not to be among those localized bacterial infections that result in a parallel increase in this inflammatory marker. First of all, uncomplicated acute appendicitis does not cause significant bacterial translocation. This has been shown in a study by Aslan et al. [19], where only 3 of 18 patients (16.6\%) with acute appendicitis also included bacterial translocation to a mesenteric lymph node that was adjacent to the terminal ileum. We propose that a lipopolysaccharide-induced increase in PCT occurs mainly in cases of significant systemic bacterial translocation. This could explain the reason why the PCT response in our collective was so low. This is consistent with our results, in which patients from groups 3-5 experienced an elevation in the level of PCT.

Finally, although the appendix is the most commonly resected and examined intra-abdominal organ, the pathogenesis and etiology of acute appendicitis remains enigmatic. Reports of a viral origin of appendiceal inflammation may lend support to the theory that a viral infection may contribute in part to some cases of appendicitis and thus be relevant to the low PCT levels observed $[20,21]$.

\section{Conclusion}

As to whether or not PCT should be a marker of appendicitis in adult patients, the answer is clearly no. It is potentially increased in cases of severe inflammation and, in particular, after appendiceal perforation or gangrenous appendicitis, which confirms its broad usage as a sepsis marker. However, its frequency of elevation with a remarkably poor sensitivity of 0.14 prohibits its use as a standard laboratory test for the diagnosis of acute or chronic appendicitis.

\section{Financial Disclosure}

All authors hereby disclose any commercial associations which might pose or create a conflict of interest with information presented in the manuscript.

\section{Ethics}

This study was conducted in compliance with the applicable local requirements with regard to the ethics and investigational committee review, informed consent, and other statutes or regulations regarding the protection of the rights and welfare of human subjects participating in medical research (ClinicalTrials. gov identifier: NCT00630071, Ethics Review Board of the Ruhr University Bochum, Germany, registration No.: 3133-08).

\section{References}

$>_{1}$ Blomqvist PG, Andersson RE, Granath F, Lambe MP, Ekbom AR: Mortality after appendectomy in Sweden, 1987-1996. Ann Surg 2001;233:455-460.

-2 Schwarz A, Bolke E, Peiper M, Schulte am Esch J, Steinbach G, van Griensven M, et al: Inflammatory peritoneal reaction after perforated appendicitis: continuous peritoneal lavage versus nonlavage. Eur J Med Res 2007; 12:200-205.

$\checkmark 3$ Carrol ED, Thomson AP, Hart CA: Procalcitonin as a marker of sepsis. Int J Antimicrob Agents 2002;20:1-9.

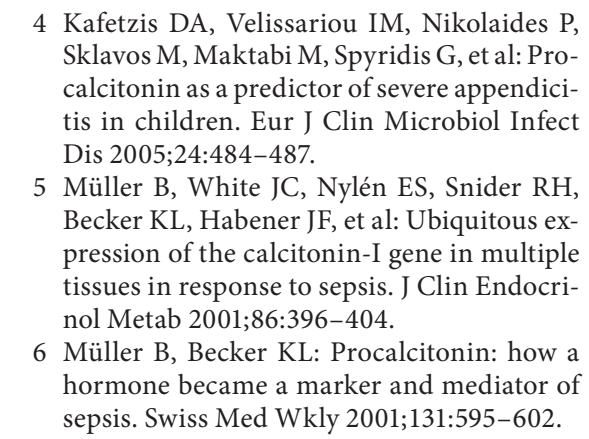
Kafetzis DA, Velissariou IM, Nikolaides P,
Sklavos M, Maktabi M, Spyridis G, et al: Procalcitonin as a predictor of severe appendicitis in children. Eur J Clin Microbiol Infect Dis 2005;24:484-487.

Müller B, White JC, Nylén ES, Snider RH, pression of the calcitonin-I gene in multiple tissues in response to sepsis. J Clin Endocrinol Metab 2001;86:396-404.

hormone became a marker and mediator of sepsis. Swiss Med Wkly 2001;131:595-602.
7 Christ-Crain M, Jaccard-Stolz D, Bingisser R, Gencay MM, Huber PR, Tamm M, et al: Effect of procalcitonin-guided treatment on antibiotic use and outcome in lower respiratory tract infections: cluster-randomised, single-blinded intervention trial. Lancet 2004;363:600-607.

$\checkmark 8$ Marc E, Ménager C, Moulin F, Stos B, Chalumeau M, Guérin S, et al: Procalcitonin and viral meningitis: reduction of unnecessary antibiotics by measurement during an outbreak. Arch Pediatr 2002;9:358-364. 
-9 Mueller C, Huber P, Laifer G, Mueller B, Perruchoud AP, et al: Procalcitonin and the early diagnosis of infective endocarditis. Circulation 2004;109:1707-1710.

10 Oláh A, Belágyi T, Issekutz A, Makay R, Zaborszky A: Value of procalcitonin quick test in the differentiation between sterile and infected forms of acute pancreatitis. Hepatogastroenterology 2005;52:243-245.

11 Schwartz SL: Principles of Surgery, ed 5. New York, Mc Graw-Hill, 1989, appendix, chapt 29, pp 1315-1326.

12 Brunkhorst FM, Heinz U, Forycki ZF: Kinetics of procalcitonin in iatrogenic sepsis. Intensive Care Med 1998;24:888-892.

-13 Assicot M, Gendrel D, Carsin H, Raymond J, Guilbaud J, Bohuon C: High serum procalcitonin concentrations in patients with sepsis and infection. Lancet 1993;341:515-518.
4 Kisacik B, Kalyoncu U, Erol MF, Karadag O, Yildiz M, Akdogan A, et al: Accurate diagnosis of acute abdomen in FMF and acute appendicitis patients: how can we use procalcitonin? Clin Rheumatol 2007;26:2059-2062.

15 Blab E, Kohlhuber U, Tillawi S, Schweitzer M, Stangl G, Ogris E, et al: Advancements in the diagnosis of acute appendicitis in children and adolescents. Eur J Pediatr Surg 2004;14:404-409.

16 Kouame DB, Garrigue MA, Lardy H, Machet MC, Giraudeau B, Robert M: Is procalcitonin able to help in pediatric appendicitis diagnosis? Ann Chir 2005;130:169-174.

17 Chakhunashvili L, Samkharadze J, Chkhaidze I: Procalcitonin as the biomarker of inflammation in diagnostics of pediatric appendicitis and for prevention of unnecessary appendectomy. ABRE 2005;5:6-9.
8 Sack U, Biereder B, Elouahidi T, Bauer K, Keller T, Tröbs RB: Diagnostic value of blood inflammatory markers for detection of acute appendicitis in children. BMC Surg 2006;6: 15.

19 Aslan A, Karaveli C, Ogunc D, Elpek O, Karaguzel G, Melikoglu M: Does noncomplicated acute appendicitis cause bacterial translocation? Pediatr Surg Int 2007;23:555558.

20 Wang G, An AP, Deng LF, et al: A study on virology of viral appendicitis in children. Abstracts 23rd Int Congr Paediatr, Beijing, September 2001.

21 Grynspan D, Rabah R: Adenoviral appendicitis presenting clinically as acute appendicitis. Pediatr Dev Pathol 2008;11:138-141. 